\section{INTERNATIONAL MEETING ON ANIMAL PRODUCTION}

\author{
By I. L. MASON \\ Assistant Director, Commonwealth Bureau of Animal \\ Breeding and Genetics, Edinburgh
}

A MEETING, sponsored by the Swiss Zootechnical Society, was held in Zurich during October 8-9, 1947, in order to renew professional and personal contacts severed by the War and to discuss the proposed formation of an International Society of Zootechny (or Animal Production). It was organised by Dr. W. Engeler, secretary of the Swiss society, and great credit is due to him and his colleagues for arranging the meeting at such short notice.

There were about 250 participants from twenty-six countries, and eighteen of these countries were represented by official Government delegates. Apparently the only delegate from outside Europe was Dr. Riddell, the United States agricultural attaché at The Hague, who was the official American representative. The only visitors from Great Britain were Mr. Alec Hobson (secretary of the Royal Agricultural Society of England and also representing the British Society of Animal Production), Mr. and Mrs. Gerald Strutt (Royal Agricultural Society of England), and Mr. and Mrs. I. L. Mason.

At the opening ceremony addresses of welcome were given by representatives of the Federal Department of Agriculture, the Swiss Zootechnical Society, the Swiss Breeders' Federation, and the Federal Technical College, where the meetings were held. All the speakers recalled with pleasure the International Conference on Animal Breeding held in Zurich in 1939, and hoped that the work interrupted by the War could now be continued.

At the first technical session, Dr. I. Moskovits, head of the animal husbandry section of the Temporary European Bureau of the Food and Agriculture Organisation, Rome, gave an exhaustive account of the international livestock situation, with particular reference to changes in livestock numbers, country by country, during the War, and Dr. A. Kiener presented a vivid picture of the Swiss livestock industry. It was very interesting to observe that the War had had much the same effects on livestock production policy in Switzerland as in Britain, namely, sharp reduction in pig and poultry stocks, owing to absence of imported feeding-stuffs, and emphasis on milk rather than on meat production.

On the second day of the meeting, official reports on the state of animal breeding in the following European countries were circulated: Austria, Belgium, Denmark, Finland, France and the Netherlands. In addition, Dr. Riddell and Prof. Csukás gave verbal accounts of animal breeding in the United States and Hungary respectively. Dr. H. Aersoe spoke on bull testing in Denmark; this information is already available in published form (226. Beretning fra Forsøgslaboratoriet, Copenhagen, 1947). In the discussion, Dr. Rijssenbeek (Netherlands) criticized the absence of daughter/dam comparisons and the restriction of the test to autumn calve:s. Dr. Horn (Hungary) pointed out the difficulty of comparing one year with another in a Continental climate; his observations also showed that some bulls might raise the annual yield, but depress the life-time production of daughters compared with dams. Dr. Rijssenbeek read a paper entitled "Horse-Breeding in the Netherlands"; it included an account of an apparatus for measuring the pulling power of horses, designed by Prof. Visser.

The rest of the day was devoted to the proposed International Society of Animal Production. The discussion was based on the provisional statutes drawn up by the 1939 meeting. Those most desirous of forming the Society were Dr. Rijssenbeek, Dr. Engeler and Prof. Leroy (France). It was finally decided : (1) that an International Society of Animal Production should be formed on a Continental basis; the Continental sections could later link to form a world association; (2) that the society should be private and not governmental, and should be based on the zootechnical societies of each country; these societies include scientific workers, breeders, and administrators; (3) that a preparatory committee should be formed by representatives of the national zootechnical societies in Belgium, Denmark, France, Hungary, Netherlands, Switzerland and the United Kingdom; (4) that the secretariat should be at the Food and Agriculture Organisation Bureau in Rome, and Dr. Moskovits would be responsible for convening the committee; (5) that the committee should prepare a draft constitution and report at the next International Meeting on Animal Production, to be held in Paris in 1949. The preparatory committee would also prepare the agenda for the next conference. Dr. Moskovits suggested that the projected International Society might help to co-ordinate the research programmes in the smaller countries. At the moment, too many small experiment stations are attempting too much for their resources and achieving too little. Mr. Hobson described the formation and objects of the British Society of Animal Production, and promised its co-operation.

The meeting was conveniently arranged to coincide with the sixteenth Swiss National Livestock Show. This is a big event, lasting for nearly a month, horses, small stock and cattle being shown in succession. Judging was done before the public was admitted, and the prize animals were periodically paraded round the ring. In this parade, however, the emphasis was on the breed rather than the individual, and attention was directed to the characteristics, distribution and performance of each. In this way we were able to see the famous improved breeds of Swiss goats-the Saanen, Toggenburg, Appenzell, and polled Chamois-as well as the horned Chamois, Grisons, Verzasca, and Valais Blackneck, representing the mountain types. Most of the pigs in the country are Improved Landschwein or Large White. Sheep are of less importance; we saw the White Swiss Alpine, Brown-headed Mutton (Oxford) and the Black-brown Mountain breeds.

Cattle are by far the most important livestock in Switzerland. Two breeds divide the country between them-the Swiss Brown in the east and the Simmental in the west. They were excellently presented at the show, and in view of the single- versus dual. purpose controversy in Great Britain, it was extremely interesting to see such good examples of functional triple-purpose animals. In presenting them, the emphasis was placed on the importance of maintaining a balance between the production of milk, work and meat.

Further opportunity of studying these animals was provided by the expeditions organised in connexion with the meeting. We went to Einsiedeln in Canton Schwyz, the place of origin not only of the Swiss Brown cattle, but also of the Swiss Confederation itself. We saw three herds of Simmental cattle in the 
Emmental and Simmental. Finally, we inspected Jura (or Freiberg) horses in the neighbourhood of Delémont, in the Bernese Juras. This is the only native Swiss breed; it is a light-draft type, developed during the last fifty years. Wherever we went we were warmly welcomed and most hospitably entertained.

The arrangements for the conference were excellent. It is all the more unfortunate that the currency restrictions which prevail at every frontier prevented many people attending the conference and reduced to a minimum the stay of many others. Voluminous literature was available about the Swiss breeds of livestock. More important, these books and brochures were not merely propaganda, but gave factual accounts of characteristics and performance of animals and of methods of breeding and herd book registration.

\section{INSULATING MATERIALS AND METHODS FOR USE AT LOW TEMPERATURES}

$\mathrm{T}$

HE Low Temperature Group of the Physical Society at a meeting on December 18, 1947, discussed insulating materials for use at low temperatures.

Sir Alfred Egerton, in the course of his presidential address to the Group, referred to the fact that the heat transfer by radiation in vacuum-jacketed vessels is greater than that predicted from theoretical calculations based on emissivities obtained from the electrical conductivities, and mentioned that a copper surface reduced with hydrogen at $300^{\circ} \mathrm{C}$. is a better reflector for heat waves than a polished surface.

Sir Alfred then described thermal conductivity determinations carried out under his and Prof. Newitt's direction by Dr. C. S. Chow at the Imperial College. The apparatus consisted of an inner cylinder maintained at low temperature by liquid oxygen and an outer cylinder which served both as a heater and a water flow-calorimeter; the material under test being packed between. Thermocouples were located at various positions to give the temperature distribution. Some of the data obtained are quoted below. They are mean thermal conductivities for a cold-face temperature of $-181^{\circ} \mathrm{C}$. and a mean temperature of about $-84^{\circ} \mathrm{C}$.

\begin{tabular}{|c|c|c|c|}
\hline Material & Description & $\begin{array}{c}\text { Bulk } \\
\text { density } \\
\text { (gm./c.c.) }\end{array}$ & $\begin{array}{l}\text { Thermal } \\
\text { conductivity } \\
\text { (gm. cal. cm./ } \\
\left.\mathrm{cm}^{2} \text { sec. }^{\circ} \mathrm{C} .\right)\end{array}$ \\
\hline $\begin{array}{l}\text { Granulated cork, } \\
\text { baked }\end{array}$ & $\begin{array}{l}49.5 \% \text { 10-20 mesh } \\
50.5 \% \text { through } 20 \\
\text { mesh }\end{array}$ & $0 \cdot 101$ & $0 \cdot 000066$ \\
\hline Vermiculite & $\begin{array}{r}10-14 \text { mesh } \\
\text { 4-10 mesh }\end{array}$ & $\begin{array}{l}0 \cdot 216 \\
0 \cdot 144\end{array}$ & $\begin{array}{l}0 \cdot 000112 \\
0 \cdot 000082\end{array}$ \\
\hline Mixed ," & $\left.\begin{array}{l}7 \cdot 9 \% 3-4 \text { mesh } \\
26 \cdot 5 \% \text { 4-10 }, \\
65 \cdot 6 \% 10-14,\end{array}\right\}$ & $0 \cdot 157$ & 0.000101 \\
\hline $\begin{array}{l}\text { Wadding } \\
\text { Slag wool }\end{array}$ & Crude cotton wool & $\begin{array}{l}0 \cdot 042 \\
0 \cdot 059 \\
0.130\end{array}$ & $\begin{array}{l}0.000062 \\
0.000076\end{array}$ \\
\hline ", ", & & $\begin{array}{l}0 \cdot 130 \\
0 \cdot 197\end{array}$ & $\begin{array}{l}0.000044 \\
0.000062\end{array}$ \\
\hline Cotton waste & $\begin{array}{l}\text { Tangled thread } \\
\text { form }\end{array}$ & $0 \cdot 131$ & $0 \cdot 000092$ \\
\hline
\end{tabular}

In a contribution from the National Physical Laboratory, Dr. Ezer Griffiths and Mr. M. J. Hickman reviewed the physical properties of insulating materials which have to be taken into account in practice in addition to thermal conductivity. They are bulk density, specific heat, fire resistance, water absorption, water repellency, permeability to water vapour, mechanical strength and settlement under vibration. The procedures for measuring these properties were outlined. For measuring thermal conductivity over the range of temperature of interest in refrigeration work, the hot-plate method was adopted: the plate being fitted with a coplanar guard ring. For the measurement of thermal conductivity down to about $-78^{\circ} \mathrm{C}$, a box or cylinder method has been used, the box being made of the material under test. The cold-face temperature was maintained at a constant low temperature by the use of a block of solid carbon dioxide, and the rate of sublimation of the solid carbon dioxide afforded a measure of the heat flow into the box.

A few of the results obtained with the various forms of apparatus are summarized below:

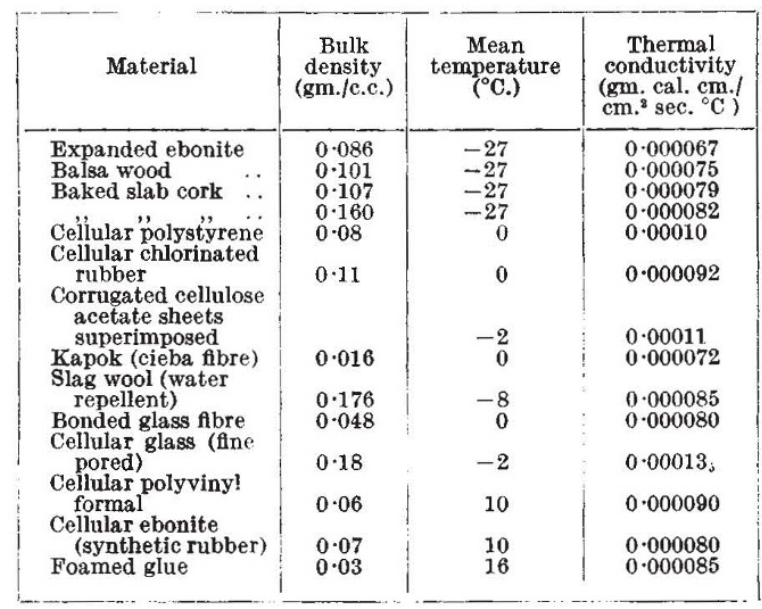

Dr. A. M. Clark (British Oxygen Co.) stated that the energy required to compensate the leakage of a unit of heat into a system at liquid oxygen temperature is fifteen to twenty times as great as that required to compensate for the leakage of the same quantity of heat at $-30^{\circ} \mathrm{C}$. The efficiency of a vacuum at liquid air temperature is about fourteen times that of a $10-\mathrm{cm}$. layer of a material such as baked slab cork. The complexity of the arrangement of a large industrial low-temperature plant, however, renders vacuum insulation impracticable to any great extent. He stated that the largest vacuum-insulated tank yet made for the storage of liquid oxygen had a capacity of 57 tons and an evaporation loss of 0.16 per cent of its contents per 24 hours. The largest storage vessel insulated with rock wool had an evaporation loss on the same basis of 0.2 per cent.

Sir Alfred Egerton stated that a vacuum-jacketed vessel of 30 gallons capacity for the storage of liquid methane had a rate of loss of $1 \frac{1}{2}$ gallons per 24 hours.

Dr. P. M. Schuftan (Gas Separation Branch, British Oxygen Co.) gave figures to show that the effect of improved insulation in oxygen plants was rather smaller than expected. For example, in an oxygen storage tank of $300,000 \mathrm{ft}^{3}$ capacity fitted with the usual magnesia insulation, about 3 per cent of the product is gasified by heat influx from outside. This amount of gas can, as a rule, be fully utilized for cylinder filling and only the latent heat of the oxygen is lost, adding about 2 per cent to power consumption and 1 per cent to total operating costs. 